\title{
Old carbon contributes to aquatic emissions of carbon dioxide in the Amazon
}

\author{
L. E. Vihermaa ${ }^{1}$, S. Waldron ${ }^{1}$, M. H. Garnett ${ }^{2}$, and J. Newton ${ }^{3}$ \\ ${ }^{1}$ School of Geographical and Earth Sciences, University of Glasgow, Glasgow, UK \\ ${ }^{2}$ NERC Radiocarbon Facility, East Kilbride, UK \\ ${ }^{3}$ Scottish Universities Environmental Research Centre (SUERC), East Kilbride, UK \\ Correspondence to: L. E. Vihermaa (leena.vihermaa@glasgow.ac.uk)
}

Received: 20 December 2013 - Published in Biogeosciences Discuss.: 29 January 2014

Revised: 30 April 2014 - Accepted: 21 May 2014 - Published: 4 July 2014

\begin{abstract}
Knowing the rate at which carbon is cycled is crucial to understanding the dynamics of carbon transfer pathways. Recent technical developments now support measurement of the ${ }^{14} \mathrm{C}$ age of evaded $\mathrm{CO}_{2}$ from fluvial systems, which provides an important "fingerprint" of the source of $\mathrm{C}$. Here we report the first direct measurements of the ${ }^{14} \mathrm{C}$ age of effluxed $\mathrm{CO}_{2}$ from two small streams and two rivers within the western Amazonian Basin. The rate of degassing and hydrochemical controls on degassing are also considered. We observe that $\mathrm{CO}_{2}$ efflux from all systems except for the seasonal small stream was ${ }^{14} \mathrm{C}$-depleted relative to the contemporary atmosphere, indicating a contribution from "old" carbon fixed before $~ 1955$ AD. Further, "old" $\mathrm{CO}_{2}$ was effluxed from the perennial stream in the rainforest; this was unexpected as here connectivity with the contemporary $\mathrm{C}$ cycle is likely greatest. The effluxed gas represents all sources of $\mathrm{CO}_{2}$ in the aquatic system and thus we used end-member analysis to identify the relative inputs of fossil, modern and intermediately aged $\mathrm{C}$. The most likely solutions indicated a contribution from fossil carbon sources of between 3 and $9 \%$ which we interpret as being derived from carbonate weathering. This is significant as the currently observed intensification of weather has the potential to increase the future release of old carbon, which can be subsequently degassed to the atmosphere, and so renders older, slower $\mathrm{C}$ cycles faster. Thus ${ }^{14} \mathrm{C}$ fingerprinting of evaded $\mathrm{CO}_{2}$ provides understanding which is essential to more accurately model the carbon cycle in the Amazon Basin.
\end{abstract}

\section{Introduction}

Aquatic $\mathrm{CO}_{2}$ outgassing from the Amazon Basin has been estimated as $0.5 \mathrm{Gt} \mathrm{C} \mathrm{yr}^{-1}$ (Richey et al., 2002), equivalent to emissions from South American deforestation (Gloor et al., 2012). When revised gas transfer velocity estimates have been applied to this basin-wide upscaling, the aquatic efflux is likely to be considerably higher, up to $\sim 50-70 \%$ greater in the Amazon main tributaries alone (Alin et al., 2011). The aquatic efflux is attributed to rapidly cycled ecosystemderived carbon (Richey et al., 2002; Mayorga et al., 2005), rather than slow release from older reservoirs. Recently, in situ decomposition of lignin (Ward et al., 2013) or $\mathrm{CO}_{2}$ released by wetland plants (Abril et al., 2013) have been advocated as sources of the effluxed carbon dioxide. However, in samples from mountainous or mixed sites, old carbon can be present (Mayorga et al., 2005) and some fossil particulate carbon can persist into the lowland Amazon (Clark et al., 2013). Young riverine efflux can be considered as internal recycling within the basin (Gloor et al., 2012). However, if the efflux includes oxidation of fossil carbon this constitutes an input of stored $\mathrm{CO}_{2}$ to the atmosphere (Berner, 2003), and requires adjustment of carbon balance models. Climate change impact models (Huntingford et al., 2013; Bony et al., 2013) do not separate weathering-derived carbon or include rates of carbon movement. To accurately model the response of important carbon landscapes such as the Amazon Basin to land use and climatic change, the efficacy of slower $\mathrm{C}$ cycles and the source of this $\mathrm{C}$ must be fully understood.

The $\mathrm{C}$ load to a river and its $\mathrm{CO}_{2}$ efflux can be derived from multiple sources. For example fossil carbon can come from weathering of carbonate and sedimentary rocks (Co- 
pard et al., 2007) releasing inorganic and organic carbon, respectively. These sources are millions of years old and "radiocarbon dead" (i.e. so old that the radiocarbon they once contained has decayed to background levels). Younger, but still old carbon could be derived from soil carbon stocks, including black carbon formed in fires (McMichael et al., 2012), from peat deposits (Householder et al., 2012) or erosion of river bank sediments (Rigsby et al., 2009). These aged fractions are mixed with the inputs from contemporaneous vegetation either as dissolved organic carbon (DOC), particulate organic carbon (POC) or dissolved inorganic carbon (DIC).

Fine particulate organic carbon (FPOC $<63 \mu \mathrm{m}$ ) is mainly derived from soils and coarse particulate organic carbon (CPOC, $>63 \mu \mathrm{m}$ ) from plant material (Hedges et al., 1986a, 2000; Townsend-Small et al., 2005), the former being older due to aging in soil (Hedges et al., 1986a). In addition to ecosystem-derived carbon, POC may include kerogen from sedimentary rocks. Once the mineral-protected fossil organic matter is released to the aquatic system, it is labile and can be respired quickly (Petsch et al., 2000) and hence contribute to the outgassed $\mathrm{CO}_{2}$. In Madre de Dios headwaters, in the western part of the Amazon Basin where our study site is located, ${ }^{14} \mathrm{C}$ date of POC ranged from approximately 120 to $9900 \mathrm{yr} \mathrm{BP}$ (in years $\mathrm{BP}$; where $0 \mathrm{BP}=1950 \mathrm{AD}$ (corresponding to $98.5-28.9 \%$ modern)) with fossil POC found to constitute up to $80 \%$ of the total POC (Clark et al., 2013).

The floodplain soils of western Amazonia are not much older than $5000 \mathrm{yr}$ (Quesada et al., 2011) and the soils' organic matter is probably considerably younger. In the upper part of the Amazon main stem, fine suspended particulate organic matter (FPOM) that is thought to originate from soils (Hedges et al., 2000; Townsend-Small et al., 2005) had a ${ }^{14} \mathrm{C}$ content of 101.9 $\pm 1.9 \%$ modern (measured in 1983; Hedges et al., 1986b) - a mixture of pre- and post-bomb material most likely dominated by pre-bomb contributions, indicating an aged soil-derived component. Some wildfire-derived black carbon dated to $1100-4000 \mathrm{yr}$ BP has been detected in soils of southeastern Peru, with ages older than $500 \mathrm{yr}$ below $20 \mathrm{~cm}$ depth (McMichael et al., 2012). The Quaternary Madre de Dios Basin, in which the Tambopata catchment is nested, has undergone several sedimentation and undercutting sequences, with the most recent bank sediment deposition starting approximately $870 \mathrm{yr}$ ago: wood samples from Tambopata floodplain deposits were dated as going back to $690 \pm 20$ and $870 \pm 50 \mathrm{yr} \mathrm{BP}$ (Rigsby et al., 2009). Cutting of these river banks can contribute carbon predominantly from this period, with some additional sedimented older carbon.

The magnitude of the different source fluxes will vary in space and time in response to environmental drivers. For example, over the last few decades the Amazon has become wetter, with larger differences in minimum and peak river discharge, resulting in the increased occurrence of extreme events in the wet season (Gloor et al., 2013). Higher storm frequency increases the erosion rate and POC delivery

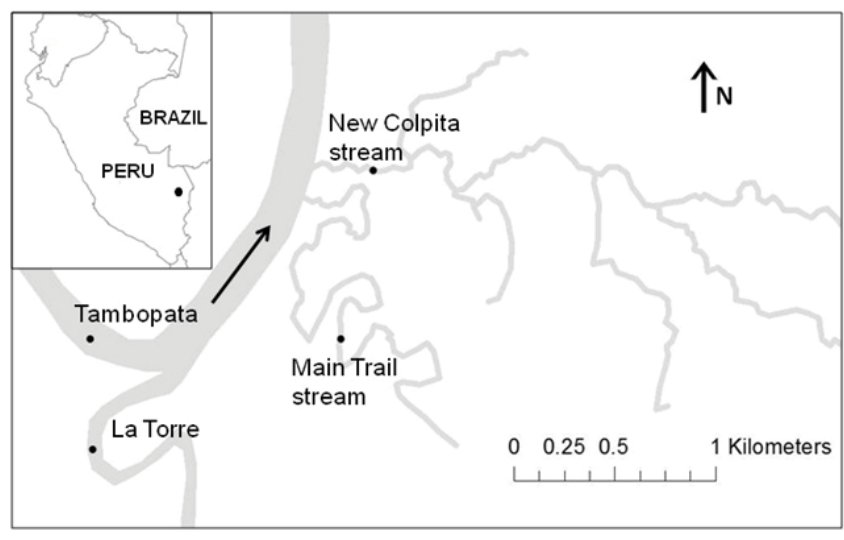

Figure 1. Location of the study area. The circle in the inset map notes the location of the study site, Tambopata National Reserve, Madre de Dios, Peru. In the study area, four independent drainage systems were sampled from 2011 to 2012 .

(Hilton et al., 2008; Leithold et al., 2006; Townsend-Small et al., 2008). Storm-induced landslides contribute significantly to fluvial POC in mountainous watersheds and increase the rock-derived "fossil" carbon fraction (Hilton et al., 2008). If the observed wetting trend continues, geomorphological controls of fluvial $\mathrm{C}$ influx are likely to become more important in the Amazon Basin, and thus we need to understand carbon fluxes and the related reservoir residence times. Here, we present the results of a study to investigate controls on the rate of $\mathrm{CO}_{2}$ efflux through isotopic and hydrochemical measurements. Although ${ }^{14} \mathrm{C}$-DIC has been measured in largescale sampling of different parts of the Amazonian Basin (Mayorga et al., 2005), our study is the first to directly measure the age of effluxed $\mathrm{CO}_{2}$ from fluvial systems of different sizes in the Amazon.

\section{Materials and methods}

\subsection{Study site}

Four drainage systems in the more fertile (Quesada et al., 2010) western part of the Amazon Basin in Tambopata National Reserve, Madre de Dios region, Peru (Fig. 1), were studied. These drainage systems comprised rivers, La Torre and Tambopata, and two small streams draining the local forest area. According to the Amazonian river types classification (Sioli, 1984) the studied rivers are of the white water type that are characterized by a high suspended sediment load. One small stream, Main Trail, existed only in the wet season, whereas the other, New Colpita, was perennially present. The seasonality of the former was attributed to the absence of groundwater contribution in this stream. The catchment areas of the small streams were analysed using LiDAR data (Hill et al., 2011; Boyd et al., 2013) and those of the rivers were analysed using the Advanced Spaceborne 
Thermal Emission and Reflection Radiometer Global Digital Elevation Model from the US Geological Survey (USGS ASTER GDEM).

The climate is warm (average temperature $26^{\circ} \mathrm{C}$ ) and humid (average rainfall $1600-2400 \mathrm{~mm}$ ). Elevation above sea level is $210 \mathrm{~m}$. The soils in the area are classed as Haplic Cambisols (Inceptsols in the US Soil Taxonomy) and vary from well drained to swampy (Quesada et al., 2011). The site has a long history of biomass monitoring within the RAINFOR (The Amazon Forest Inventory Network) project (e.g. Malhi et al., 2013) and since 2011 The Ramiro Chacon SAGES eddy-covariance flux tower has been used to monitor $\mathrm{CO}_{2}$ and methane flux of the forest ecosystem.

\subsection{Sample analyses}

From February 2011 to October 2012, pH (Troll 9500, InSitu Inc.) and stage height (2150Flow module, ISCO Inc.) were monitored in these drainage systems. The small streams were logged continuously at $15 \mathrm{~min}$ intervals and campaigns of spot measurements were carried out in the rivers. These systems were regularly sampled for [DIC], $\delta^{13} \mathrm{C}_{\text {DIC }}$ (analysed on a Thermo-Fisher-Scientific Gas Bench/Delta V Plus), DOC (Thermalox TOC 2020, Analytical Sciences), POC (measured by loss on ignition) and $\mathrm{CO}_{2}$ evasion (floating chamber connected to an infrared gas analyser, Li-840A, LI-COR) across different seasons. Calcium concentration (measured by atomic absorption spectrometry (AAS), Perkin Elmer Analyst 400) was determined on samples collected in 2012.

Silicate weathering percentage values were calculated from the bicarbonate concentration data (derived from [DIC] and $\mathrm{pH}$ ). Silicate weathering is characterized with low instream bicarbonate whereas carbonate weathering leads to higher bicarbonate concentration. For rivers draining pure carbonate lithology the expected bicarbonate concentration has been determined as $3.195 \mathrm{mmol} \mathrm{L}^{-1}$ and pure silicate sandstone as $0.125 \mathrm{mmol} \mathrm{L}^{-1}$ (Meybeck, 1987). We used these end-member values in a mass balance calculation to derive the relative contributions from carbonate and silicate rock weathering in our study catchments.

Evasion $\mathrm{CO}_{2}$ samples were collected during AprilMay 2012 for measurement of $\delta^{13} \mathrm{C}$ and ${ }^{14} \mathrm{C}$ content. Each drainage system was sampled three times targeting different stage heights to assess hydrological controls on the ${ }^{14} \mathrm{C}$ content and $\delta^{13} \mathrm{C}$ of the evasion. Evaded fluvial $\mathrm{CO}_{2}$ was accumulated in a floating chamber (Billett et al., 2006). The chamber was first scrubbed free of atmospheric $\mathrm{CO}_{2}$ using a soda lime trap, then $\mathrm{CO}_{2}$ was allowed to accumulate in the headspace to yield sufficient material for analysis. In our systems the required accumulation time ranged from 5 to $50 \mathrm{~min}$ depending on the sampling point and hydrological conditions. Finally the gas from the headspace was trapped in a cartridge containing a 13X zeolite molecular sieve (Hardie et al., 2005). In the laboratory the $\mathrm{CO}_{2}$ was released by heat-
Table 1. Estimated average ${ }^{14} \mathrm{C}$ concentrations (\%modern) and $\delta^{13} \mathrm{C}$ signatures of the potential end members at the Tambopata site. Intermediately aged carbon date range is $\sim 200-2000 \mathrm{yr} \mathrm{BP}$ (where $0 \mathrm{BP}=1950 \mathrm{AD}$ ) which represents the age of material that could be derived from aged soil carbon, Holocene fire black carbon and reworking of the Tambopata River bank terraces. The Main Trail concentration was selected to represent the recent carbon inputs into the mixing model to solve the end members for the other three drainage systems.

\begin{tabular}{lrr}
\hline Carbon source & $\begin{array}{r}\text { Typical }{ }^{14} \mathrm{C} \\
(\% \text { modern })\end{array}$ & $\begin{array}{r}\text { Typical } \delta^{13} \mathrm{C} \\
(\%)\end{array}$ \\
\hline Young (C3 vegetation derived) & $106 \pm 0.6$ & -24 to -34 \\
Intermediately aged carbon & $88 \pm 9.5$ & -25 to -29 \\
Fossil carbon - Kerogen & 0 & -27.5 \\
Fossil carbon - marine carbonates & 0 & +1 to -3 \\
\hline
\end{tabular}

ing the molecular sieve $\left(500^{\circ} \mathrm{C}\right)$ and the gas was purified cryogenically and divided into volumes allocated for $\delta^{13} \mathrm{C}$ and ${ }^{14} \mathrm{C}$ analysis. $\delta^{13} \mathrm{C}$ was measured on a Thermo-FisherScientific Delta V mass spectrometer. The sample fraction for ${ }^{14} \mathrm{C}$ analysis was graphitized and analysed by accelerator mass spectrometry at the Scottish Universities Environmental Research Centre. Following convention, the ${ }^{14} \mathrm{C}$ results were normalized to $\delta^{13} \mathrm{C}-25 \%$ o to account for mass dependent fractionation and the results expressed as \%modern and conventional radiocarbon age (in years BP). \%modern and radiocarbon age can be related to each other by the following equation:

Conventional radiocarbon age $(\mathrm{yr} \mathrm{BP})=$

$-8033 \times \mathrm{LN}\left(\%\right.$ modern $\left.100^{-1}\right)$.

Radiocarbon concentrations exceeding $100 \%$ modern cannot be assigned a conventional radiocarbon age, but indicate the presence of bomb- ${ }^{14} \mathrm{C}$ and therefore a contribution from carbon fixed from the atmosphere post $\sim 1957 \mathrm{AD}$ (when atmospheric ${ }^{14} \mathrm{CO}_{2}$ first exceeded $100 \%$ modern (Levin et al., 2008)). In contrast, radiocarbon concentrations below $100 \%$ modern unambiguously indicate the presence of prebomb ("old") carbon.

\subsection{End-member mixing analysis to assign ages to $\mathrm{CO}_{2}$ efflux}

To estimate the source of the effluxed $\mathrm{CO}_{2}$ we applied the SIAR (Stable Isotope Analysis in R) package developed for stable isotope end-member analysis (Parnell et al., 2010). The DIC pool behaves conservatively within the $\mathrm{pH}$ range from 4.6 to 7.2 (Polsenaere and Abril, 2012), with addition or subtraction of $\mathrm{CO}_{2}$ only influencing the $\mathrm{CO}_{2}$ and total DIC concentration, but with no alteration of the bicarbonate pool. However the fractions of DIC pool are open to isotopic exchange. Thus although we have measurements of 
Table 2. The mean evasion ${ }^{14} \mathrm{C}$ and $\delta^{13} \mathrm{C}$ signatures, total DIC pool concentration, $\delta^{13} \mathrm{C}$-DIC, $\mathrm{pH}$, fraction of the DIC pool in the form of $\mathrm{CO}_{2}$, DOC, POC and $\mathrm{Ca}$ concentrations in the studied drainage systems in Tambopata region, Peru. The drainage systems were sampled three times targeting different hydrological conditions: baseflow, rising water and falling water. In the case of the small streams, water level is the stream depth; in larger rivers the measurement is a relative change in water level. At the time of sampling, April-May 2012, the estimated ${ }^{14} \mathrm{C}$ of the atmosphere was $\sim 103.8 \%$ modern (Levin et al., 2008). The analytical uncertainty was $\pm 0.1 \%$ and $\pm<0.5 \%$ modern for evasion $\delta^{13} \mathrm{C}$ and ${ }^{14} \mathrm{C}$ measurements, respectively.

\begin{tabular}{|c|c|c|c|c|c|c|c|c|c|c|c|c|c|}
\hline $\begin{array}{l}\text { Sampling } \\
\text { site }\end{array}$ & $\begin{array}{c}\text { Catchment } \\
\text { size } \\
\left(\mathrm{km}^{2}\right)\end{array}$ & Date & $\begin{array}{c}\text { Water } \\
\text { level } \\
(\mathrm{m})\end{array}$ & $\begin{array}{c}\text { Evasion } \\
{ }^{14} \mathrm{C} \\
\text { (\%modern) }\end{array}$ & $\begin{array}{c}\text { Evasion } \\
\delta^{13} \mathrm{C} \\
(\% \circ)\end{array}$ & $\begin{array}{c}\mathrm{DIC} \\
\left(\mathrm{mg} \mathrm{L}^{-1}\right)\end{array}$ & $\begin{array}{c}\delta^{13} \mathrm{C}_{\mathrm{DIC}} \\
(\% \circ)\end{array}$ & $\mathrm{pH}$ & $\begin{array}{c}\% \text { DIC- } \\
\mathrm{CO}_{2}\end{array}$ & $\begin{array}{c}\mathrm{CO}_{2} \\
\text { evasion } \\
\left(\mu \mathrm{mol} \mathrm{m} \mathrm{m}^{-2} \mathrm{~s}^{-1}\right)\end{array}$ & $\begin{array}{c}\text { DOC } \\
\left(\mathrm{mg} \mathrm{L}^{-1}\right)\end{array}$ & $\begin{array}{c}\mathrm{POC} \\
\left(\mathrm{mgL}^{-1}\right)\end{array}$ & $\begin{array}{c}\mathrm{Ca} \\
\left(\mathrm{mg} \mathrm{L}^{-1}\right)\end{array}$ \\
\hline \multirow{5}{*}{$\begin{array}{l}\text { Main Trail - } \\
\text { seasonal } \\
\text { stream }\end{array}$} & \multirow[t]{5}{*}{$\sim 5$} & 4 Apr 2012 & 0.23 & 106.4 & -25.9 & 0.7 & -25.6 & 5.1 & 95 & 5.6 & 6.1 & 2.5 & 0 \\
\hline & & 9 Apr 2012 & 0.55 & 105.5 & -26.4 & 1.5 & -25.1 & 5.0 & 96 & 7.6 & 6.2 & 2.4 & 0 \\
\hline & & 11 Apr 2012 & 0.34 & 106.7 & -25.9 & 1.2 & -23.6 & 5.0 & 95 & 6.3 & 6.4 & 2.2 & 0.1 \\
\hline & & Mean & 0.37 & 106.2 & -26.0 & 1.2 & -24.4 & 5.0 & 95 & 6.5 & 6.2 & 2.4 & 0.04 \\
\hline & & $\mathrm{SD}$ & 0.16 & 0.6 & 0.3 & 0.4 & 0.8 & 0.1 & 0.6 & 1.0 & 0.2 & 0.2 & 0.08 \\
\hline \multirow{5}{*}{$\begin{array}{l}\text { New Colpita - } \\
\text { perennial } \\
\text { stream }\end{array}$} & \multirow[t]{5}{*}{$\sim 7$} & 6 Apr 2012 & 0.51 & 98.1 & -25.7 & 3.9 & -19.6 & 6.4 & 44 & 15.9 & 2.5 & 2.5 & 1.0 \\
\hline & & 9 Apr 2012 & 0.64 & 101.5 & -23.9 & 1.8 & -21.9 & 6.1 & 63 & 64.9 & 3.9 & 3.9 & 0.2 \\
\hline & & 23 May 2012 & 0.48 & 98.6 & -24.5 & 6.3 & -18.8 & 6.5 & 40 & 79.6 & 0.7 & 1.9 & 1.7 \\
\hline & & Mean & 0.54 & 99.4 & -24.7 & 4.0 & -20.1 & 6.4 & 49 & 53.5 & 2.6 & 2.8 & 1.0 \\
\hline & & SD & 0.09 & 1.8 & 0.9 & 2.2 & 1.6 & 0.2 & 12 & 33.4 & 2.7 & 1.0 & 0.8 \\
\hline \multirow{5}{*}{$\begin{array}{l}\text { La Torre - } \\
\text { river }\end{array}$} & \multirow[t]{5}{*}{$\sim 2000$} & 1 May 2012 & -1.0 & 102.8 & -21.1 & 2.4 & -15.2 & 6.5 & 44 & 7.0 & 1.9 & 3.4 & 1.4 \\
\hline & & 9 May 2012 & -1.6 & 102.2 & -21.5 & 3.6 & -14.4 & 6.4 & 43 & 18.4 & 1.5 & 2.1 & 2.4 \\
\hline & & 15 May 2012 & 1.3 & 101.4 & -23.6 & 2.7 & -18.4 & 6.5 & 41 & 6.7 & 2.0 & 19.6 & 0.5 \\
\hline & & Mean & -1.4 & 102.1 & -22.1 & 2.9 & -16.0 & 6.5 & 42 & 10.7 & 1.8 & 8.4 & 1.4 \\
\hline & & SD & 0.3 & 0.7 & 1.3 & 0.6 & 2.1 & 0.03 & 1.6 & 6.7 & 0.3 & 9.7 & 1.0 \\
\hline \multirow{5}{*}{$\begin{array}{l}\text { Tambopata- } \\
\text { river }\end{array}$} & \multirow[t]{5}{*}{$\sim 14000$} & 4 May 2012 & -1.6 & 97.7 & -20.8 & 3.3 & -13.1 & 6.8 & 27 & 5.6 & 1.2 & 1.5 & 4.1 \\
\hline & & 11 May 2012 & -2.1 & 96.5 & -21.2 & 3.7 & -13.0 & 6.9 & 22 & 1.8 & 0.9 & 1.2 & 4.6 \\
\hline & & 13 May 2012 & -1.2 & 95.7 & -20.1 & 3.1 & -12.4 & 7.1 & 13 & 5.1 & 1.3 & 2.2 & 4.4 \\
\hline & & Mean & -1.6 & 96.6 & -20.6 & 3.4 & -12.9 & 6.9 & 21 & 4.2 & 1.2 & 1.6 & 4.4 \\
\hline & & SD & 0.5 & 1.0 & 0.5 & 0.3 & 0.4 & 0.2 & 7.0 & 2.1 & 0.2 & 0.5 & 0.2 \\
\hline
\end{tabular}

$\delta^{13} \mathrm{C}_{\text {DIC }}$, outgassing changes the isotopic signatures of all constituents as well as the DIC pool as a whole (Polsenaere and Abril, 2012; Doctor et al., 2008). The adulteration of the $\delta^{13} \mathrm{C}_{\mathrm{DIC}}$ signature can undermine the use of a dual carbon isotope approach for partitioning the carbon sources of $\mathrm{CO}_{2}$ evasion, although partitioning by hydrological conditions still reveals changing dominance of sources (Waldron et al., 2007). Therefore only the ${ }^{14} \mathrm{C}$ values were used in SIAR analysis. We chose this approach as the SIAR (Parnell et al., 2010) Bayesian mixing model allows incorporation of uncertainties in the source composition estimates and, therefore, mean age estimate and the ranges (as represented by the standard deviation) could be used in the model to derive the potential contributions of mixtures of carbon pools of different ages.

The ${ }^{14} \mathrm{C}$ age range is constrained by the end members of organic matter containing recently fixed $\mathrm{CO}_{2}$ and fossil contributions from weathering of sedimentary rock containing kerogen (Bouchez et al., 2010; Copard et al., 2007) or carbonate rocks, both of which are millions of years in age and hence devoid of radiocarbon. In addition to these end members, carbon aged from 100 years to some millennia could be derived from a variety of sources. We identified the endmember components and used isotopic signatures from the relevant literature for the mixing model (Table 1) based on the following understanding.
The young end-member: atmospheric nuclear weapons testing in the $1950 \mathrm{~s}-1960$ s released ${ }^{14} \mathrm{C}$ (bomb- ${ }^{14} \mathrm{C}$ ) into the atmosphere resulting in plant material fixed since the mid-1950s having ${ }^{14} \mathrm{C}$ concentrations $>100 \%$ modern. Similarly, soil organic matter derived from plants grown since the mid-1950s also has a ${ }^{14} \mathrm{C}$ concentration $>100 \%$ modern. Bomb- $-{ }^{14} \mathrm{C}$ has also been detected in coarse suspended particulate organic matter (123\% modern), whereas it was a very minor component in fine suspended particulate organic material (SPOM) (102\%modern, sampled in 1983) (Hedges et al., 1986b). In Rio Negro and main stem Amazon, humic and fulvic acid ${ }^{14} \mathrm{C}$ concentrations were 114 118 and $129-134 \%$ modern, respectively, indicating incorporation of bomb- ${ }^{14} \mathrm{C}$ (Hedges et al., 1986b). Our ${ }^{14} \mathrm{C}$ analyses indicated that the seasonal stream, Main Trail, only effluxed young carbon (Table 2). Main Trail ${ }^{14} \mathrm{C}$ concentrations (106 $\pm 0.6 \%$ modern) show incorporation of bomb${ }^{14} \mathrm{C}$ as it is higher than the atmospheric concentration (103.8\% modern in 2012; Levin et al., 2008).

The intermediate end-member: soil organic matter (potentially containing black carbon) and erosion of river bank sediments could contribute aged carbon. Compared to the fossil material, these medium-aged fractions are relatively similar in ${ }^{14} \mathrm{C}$ age and were pooled in the model to give our intermediate end-member and assigned an age of $88 \pm 9.5 \%$ modern (date range 200-2000 yr BP). 
Table 3. Spearman rho, $p$ values and sample sizes $(n)$ for correlations that indicate carbonate weathering contributions.

\begin{tabular}{lrrrrrrrrr}
\hline & \multicolumn{3}{c}{$[\mathrm{DIC}],[\mathrm{Ca}]$} & & \multicolumn{4}{c}{$[\mathrm{DIC}], \delta^{13} \mathrm{C}_{\text {DIC }}$} \\
\cline { 2 - 3 } \cline { 7 - 9 } Drainage system & $\begin{array}{r}\text { Spearman } \\
\text { rho }\end{array}$ & $p$ value & $n$ & & $\begin{array}{r}\text { Spearman } \\
\text { rho }\end{array}$ & $p$ value & $n$ \\
\hline Main Trail & 0 & $1^{*}$ & 39 & & 0.21 & 0.033 & 103 \\
New Colpita & 0.86 & $<0.001$ & 53 & & 0.86 & $<0.001$ & 172 \\
La Torre & 0.89 & $<0.001$ & 14 & & 0.51 & $<0.001$ & 126 \\
Tambopata & 0.65 & $<0.001$ & 30 & & 0.11 & 0.32 & 77 \\
\hline
\end{tabular}

* Due to multiple ties in ranks (no calcium detected) an accurate $p$ value could not be computed for Main Trail [DIC]-[Ca] correlation.

The fossil end-member: weathering-derived organic carbon from sedimentary rocks and inorganic carbon from carbonate-bearing rocks, both aged millions of years, are characterized by a ${ }^{14} \mathrm{C}$ concentration of $0 \%$ modern and so is the fossil end-member.

\subsection{Treatment of stable isotope data}

Terrestrial C3 plants have $\delta^{13} \mathrm{C}$ between -24 and $-34 \%$ o (Faure, 1986), bulk soil organic matter in $\mathrm{C} 3$ forested areas $\delta^{13} \mathrm{C}$ is -27 to $-29 \%$ on the surface, increasing to $-25 \%$ at depth (Bird et al., 1992), charcoal signature reflects its source (Bird et al., 1992), kerogen signature is, on average, $-27.5 \%$ (Hoefs, 2004) and marine carbonates, the only inorganic endmember, typically have a signature of +1 to $-3 \%$ (Hoefs, 2004).

Whilst degassing can enrich $\delta^{13} \mathrm{C}_{\text {DIC }}$ (Doctor et al., 2008; Polsenaere and Abril, 2012), comparison with expected sources is meaningful as it can confirm when $\delta^{13} \mathrm{C}_{\text {DIC }}$ has been little compromised. We are confident that the $\mathrm{C}$ cycle in this area is dominated by $\mathrm{C} 3$ vegetation: although $\delta^{13} \mathrm{C}_{\text {DIC }}$ was enriched, this is not from $\mathrm{C} 4$ vegetation as this is not known in the area and $\delta^{13} \mathrm{C}$ of fluvial dissolved organic matter in La Torre and Tambopata rivers was $-29.2 \%$ o $(n=1)$ and $-28.7 \% \circ(n=1)$, respectively. The foliar $\delta^{13} \mathrm{C}$ at the Tambopata site was on average $-30.6 \%$ (Fyllas et al., 2009) and carbon-content-weighted average composition of the soil organic matter was $-26.2 \%$, increasing from the $-29.4 \%$ o in the A horizon to $-25.0 \%$ in the B2 horizon (Zimmermann et al., 2009).

\section{Results}

Radiocarbon analyses of $\mathrm{CO}_{2}$ evasion indicated that old carbon was present in all sampled systems except the seasonal small stream (Table 2). In Main Trail, the small stream was present only in the wet season, indicating that it was not groundwater fed, and ${ }^{14} \mathrm{C}$ content $(106 \%$ modern, implying carbon fixed $\sim 4-5 \mathrm{yr}$ prior to sampling) in conjunction with $\delta^{13} \mathrm{C}$ of evasion $(-26 \%$ ) reflects young, $\mathrm{C} 3-$ plant-derived organic carbon. $\mathrm{CO}_{2}$ efflux from the adjacent forested small stream, New Colpita, was more ${ }^{13} \mathrm{C}$-enriched $\left(-24.7 \%\right.$ ) and older, with ${ }^{14} \mathrm{C}$ content (99\%modern) indicating a component of carbon fixed before AD 1957. La Torre River efflux had ${ }^{14} \mathrm{C}$ content intermediate between the two forested streams (102\%modern), suggesting that it contained both pre- and post-bomb carbon, and it was more ${ }^{13} \mathrm{C}$-enriched $\left(\delta^{13} \mathrm{C}\right.$ of $-22.1 \%$ ) . The oldest $\mathrm{CO}_{2}$ efflux was from the largest river, the Tambopata (97\%modern), which also had the most ${ }^{13} \mathrm{C}$-enriched evasion and DIC $(-20.6$ and $-12.9 \%$, respectively).

In addition to detecting old carbon in effluxed $\mathrm{CO}_{2}$, spatial variation in ${ }^{14} \mathrm{C}$ age within a small area and intra-site temporal variation under different hydrological conditions was observed. At higher flow, New Colpita [DIC] was halved due to dilution, $\delta^{13} \mathrm{C}_{\mathrm{DIC}}$ decreased and approached the composition of Main Trail, and the ${ }^{14} \mathrm{C}$ content of evasion increased, suggesting increased post-bomb $\mathrm{C}$ and indicating greater connection with the younger $\mathrm{C}$ cycle. In the La Torre River during high water (15 May 2012), both $\delta^{13} \mathrm{C}_{\text {DIC }}$ and $\delta^{13} \mathrm{C}$ of evasion decreased, but the ${ }^{14} \mathrm{C}$ content remained similar. In the Tambopata River the $\delta^{13} \mathrm{C}$ and ${ }^{14} \mathrm{C}$ content of evasion, and $\delta^{13} \mathrm{C}_{\text {DIC }}$ remained consistent across different water levels targeted in the sampling. The $\mathrm{CO}_{2}$ evasion rates measured here were comparable to the range $\left(0.18-24.3 \mu \mathrm{mol} \mathrm{m}^{-2} \mathrm{~s}^{-1}\right)$ determined in previous studies within the basin (Alin et al., 2011; Salimon et al., 2013; Neu et al., 2011; Rasera et al., 2008), apart from New Colpita, which had higher evasion rates probably resulting from greater turbulent flow, since evasion rate is strongly controlled by flow conditions (Alin et al., 2011).

With many sources that could contribute to $\mathrm{CO}_{2}$ efflux, it is challenging to identify and thus quantify the sources of old carbon. Using ${ }^{14} \mathrm{C}$ and $\delta^{13} \mathrm{C}$ data simultaneously in mass balance equations to derive unique solutions of endmember contributions (Table 2 ) is precluded by adulteration of the end-member $\delta^{13} \mathrm{C}$ through outgassing. The SIAR output for the three drainage systems (excluding Main Trail) shows that the maximum fraction of the contemporary carbon end-member was less than 1 , indicating that older carbon was being outgassed from these drainage systems. Further, 


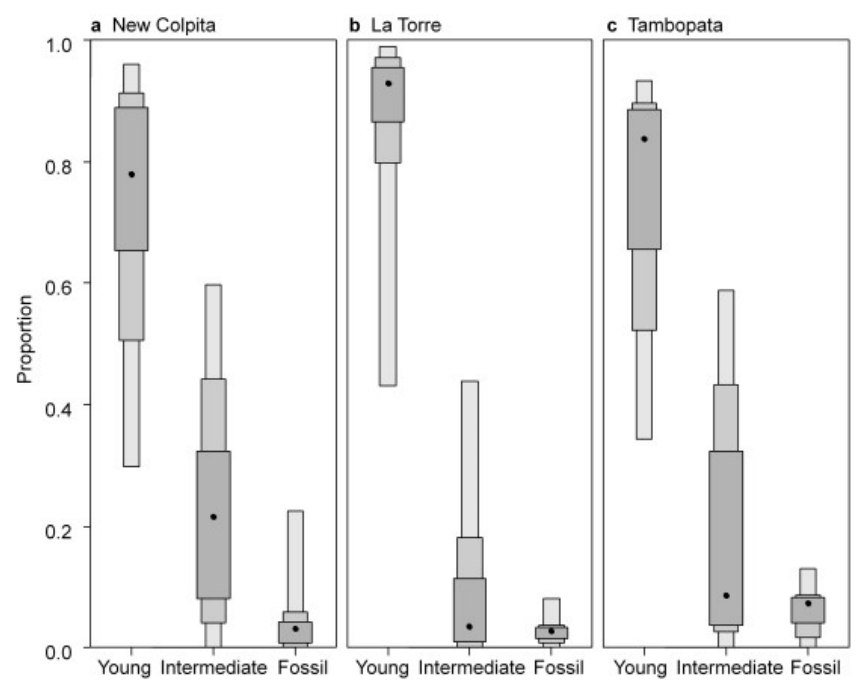

Figure 2. Potential contributions of different carbon age groups in the three drainage $(\mathbf{a}-\mathbf{c})$ systems with old carbon. The intermediateaged class includes carbon dated to $200-2000 \mathrm{yr}$ BP that could be derived from soil organic matter, black carbon or cutting of the river sediment packs. The black dot represents the most likely solution. The dark, light and lightest grey boxes represent, respectively, the 50,75 and $95 \%$ confidence intervals of the estimates. All samples contained some aged $\mathrm{C}$, but that from La Torre contained the least amount (b).

the total of intermediately aged fraction can be as high as 0.45-0.6 depending on the age of the end-member (Fig. 2).

Main Trail had the highest [DOC] and a modern ${ }^{14} \mathrm{C}$ evasion signature. During event flow, in New Colpita, [DOC] increased and the age of $\mathrm{CO}_{2}$ evaded became younger than on other sampling occasions at lower flow. $[\mathrm{POC}]$ in the four drainage systems was approximately constant (Main Trail: $2.2-2.5 \mathrm{mg} \mathrm{L}^{-1}$; New Colpita: $1.9-3.9 \mathrm{mg} \mathrm{L}^{-1}$; La Torre (excluding the event): $1.4-2.4 \mathrm{mg} \mathrm{L}^{-1}$; Tambopata: 4.1-4.6 $\mathrm{m} \mathrm{L}^{-1}$ ), except in the La Torre River where [POC] increased to $19.6 \mathrm{mg} \mathrm{L}^{-1}$ during high water. There was no relationship between $\mathrm{POC}$ and the ${ }^{14} \mathrm{C}$ content of outgassed $\mathrm{CO}_{2}$.

The dissolved calcium concentration ([Ca]) was negatively correlated with the ${ }^{14} \mathrm{C}$ content of evasion (Spearman rho $0.83, p$ value $<0.001$; Fig. $3 a$ ) and positively with the calculated silicate weathering percentage (rho $-0.88, p$ value $<0.001$; Fig. 3b). In New Colpita and La Torre there were positive correlations between [DIC] and [Ca], and between [DIC] and $\delta^{13} \mathrm{C}_{\mathrm{DIC}}$ when a larger set of data beyond the ${ }^{14} \mathrm{C}$ field campaign was analysed (Table 3). Positive [DIC]-[Ca] correlation was also significant, albeit weak ( $p$ value 0.03 ), for the Tambopata River and the [DIC]- $\delta^{13} \mathrm{C}_{\text {DIC }}$ correlation for Main Trail.
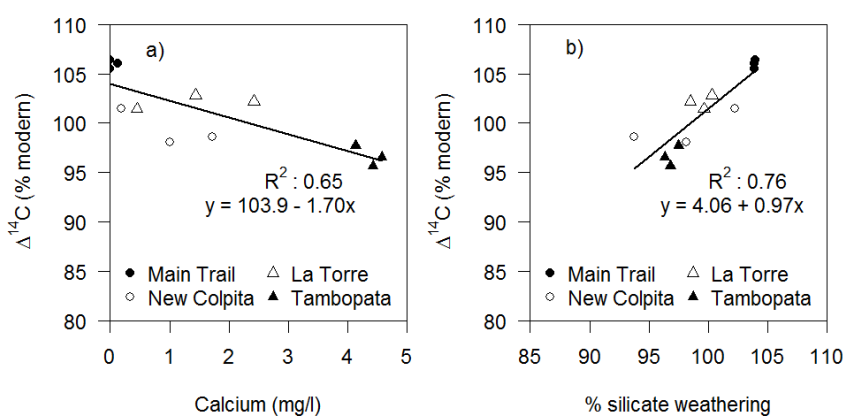

Figure 3. Across the drainage systems, ${ }^{14} \mathrm{C}$ concentration (\%modern) was significantly correlated with calcium concentration (a) and percentage silicate weathering (b). Silicate weathering percentage calculated from the bicarbonate concentration using expected in-stream concentrations in pure carbonate and silicate lithologies from Meybeck (1987).

\section{Discussion}

Our end-member mixing identifies multiple possible solutions for the proportional mixing of modern, intermediate and old carbon to $\mathrm{CO}_{2}$ efflux. However, in turn this reveals that there are multiple sources of old $\mathrm{C}$ that could contribute to $\mathrm{CO}_{2}$ efflux, and their relative contribution may change with time and environmental drivers. This temporal and spatial heterogeneity is apparent when we consider from where old carbon may be generated.

The soils at the study site have a pH below 6.5 (Quesada et al., 2010), excluding solid soil carbonates as a source of older carbon efflux from the New Colpita Stream that drains the local forest. Carbonate lithologies are found mainly in the northern Andes in Maranon and Ucayali river catchments but smaller amounts of carbonate-bearing minerals are found in the Madre de Dios region (Moquet et al., 2011). The age of evasion became older as the calcium concentration increased and silicate weathering percentage decreased (Fig. 3), indicating a contribution from carbonate weathering (Fig. 3). As the surface-water-fed seasonal stream had a contemporary ${ }^{14} \mathrm{C}$ signature and the local soils do not contain carbonate, the fossil carbonate contribution likely originates from weathering of carbonate minerals in the bed rock that enter the aquatic systems via groundwater flow. Further, the correlations observed between [DIC], [Ca] and $\delta^{13} \mathrm{C}_{\text {DIC }}$ are consistent with the influx of carbon from carbonate weathering (Doctor et al., 2008; Bullen and Kendall, 1998). As dilution of [DIC] is observed during event flow, the aged carbon is likely to enter the perennial New Colpita Stream in groundwater. Furthermore, $[\mathrm{Ca}]$ were close to zero in the surfacewater-fed seasonal stream (Main Trail) and here ${ }^{14} \mathrm{C}$ content was modern, consistent with the lack of an old carbon component due to the absence of groundwater inputs.

Samples taken at different stage heights from La Torre showed changes in $\delta^{13} \mathrm{C}$ indicative of differing contributions of C3-plant-derived material or of a change in evasion 
intensity and the related isotopic fractionation, with a higher water level characterized by more depleted DIC and evasion signatures, but little change in ${ }^{14} \mathrm{C}$ content implying no change in the age of carbon. At higher water levels the evasion rates are expected to increase due to faster and more turbulent flow conditions, which would lead to a more enriched signature. However, we observed more depleted signatures. Hence the C3 load is sufficiently greater at higher flows for the $\delta^{13} \mathrm{C}_{\text {DIC }}$ to become more depleted despite evasion. Tambopata did not show a clear change in carbon isotopic signatures with water level. In the New Colpita Stream there was an increase in ${ }^{14} \mathrm{C}$ content of evasion with higher water levels. The data set collected is limited in size and includes one season only but reveals that there are hydrological controls on the age of $\mathrm{CO}_{2}$ evasion, and these can be site specific. Further studies are needed to establish these controls.

We did not directly measure the ${ }^{14} \mathrm{C}$ concentration in DOC; however, Main Trail had the highest DOC concentrations, and evasion had a young ${ }^{14} \mathrm{C}$ signature suggesting that in situ respiration of DOC is not contributing significant quantities of aged carbon to these afforested streams. Furthermore, [DOC] increased with water level in New Colpita, but the age of evasion decreased when [DOC] were highest. These observations are consistent with the dissolved component of soil-derived material in these forested streams being young and most likely derived from surface run-off. However, the rivers sampled drain a much wider area where more aged carbon could be encountered and hence aged soil organic matter could contribute to the age of evasion in the rivers.

Chemical weathering within the Amazon Basin is estimated to produce one quarter of fossil organic carbon (43

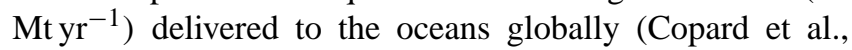
2007). For example, sedimentary rocks, mainly shale in the western Amazon Basin (Copard et al., 2007), may be a source of aged effluxed $\mathrm{CO}_{2}$. In our study region Palaeozoic shale dominates, with some evaporites present (Quesada et al., 2011). In small mountainous rivers in temperate regions, POC has been found to comprise $7-75 \%$ of kerogen, with increased sediment yield (more erosion) resulting in older POC (Leithold et al., 2006). In the Amazon Basin, fossil organic matter has been found in the form of aggregates with minerals or of free particles in sufficient quantities so that $\sim 0.25 \mathrm{MtC} \mathrm{yr}^{-1}$ of old organic material from sedimentary rocks is oxidized along the Amazonian rivers (Bouchez et al., 2010). When exposed to oxygen-rich waters, organic matter in black shales is extremely labile (Petsch et al., 2000) and the resulting dissolved organic matter (DOM) is rapidly degraded (Schillawski and Petsch, 2008). Oxidation of Cretaceous kerogen can also take place at depth in soils developed on shale parent material (Keller and Bacon, 1998). Thus old carbon delivered from weathering of rock kerogen (Petsch et al., 2000; Schillawski and Petsch, 2008) can also be a source and could be a component in the evasion samples, which would explain the ${ }^{14} \mathrm{C}$-depleted values.
Old POC (1258 yr BP, $n=1)$ has been observed at the mouth of the Amazon, whereas DOC was modern (Raymond and Bauer, 2001). In the mountainous headwater region the oldest POC samples analysed were dated to approximately 7600 yr BP (Mayorga et al., 2005) and 9900 yr BP (Clark et al., 2013). Erosion of these river bank sediments can reintroduce trapped older material to the rivers, which if respired may result in efflux of aged $\mathrm{CO}_{2}$. Furthermore black carbon can persist in soils for long periods and enter streams via erosion, providing a further aged carbon fraction. Charcoal is usually a minor fraction in the total POC budget (Bird et al., 1992) but charcoal from Holocene fires has been observed in soils of southeastern Peru (McMichael et al., 2012). Further, tropical forest burning can contribute dissolved black carbon or particulate matter for centuries to millennia after burning: in the Paraíba do Sul River, export from previously burnt Atlantic forest dissolved black carbon accounted for $7 \%$ of bulk DOC during peak flow conditions (Dittmar et al., 2012). Priming effects can render complex molecules, previously considered inherently recalcitrant, labile (Bianchi, 2011; Schmidt et al., 2011; Ward et al., 2013). Both fine and coarse POC and DOM are increasingly degraded further downstream in the Amazon, indicating sufficient residence times for decomposition to occur (Hedges et al., 2000). In our studied drainage systems there was no relationship between POC concentration and the age of evasion, indicating that in situ decomposition of POC-containing kerogen is an unlikely source of aged carbon in these systems. However, decomposition of POC could take place upstream in the catchment, be transported to the site and still potentially contribute to aged evasion $\mathrm{CO}_{2}$ detected in the rivers in this study.

Our study confirms for the first time using direct ${ }^{14} \mathrm{CO}_{2}$ analyses that aged carbon is outgassed from Amazonian river systems ranging in size from $7 \mathrm{~km}^{2}$ to $14000 \mathrm{~km}^{2}$. This phenomenon had previously been inferred from indirect measurements of ${ }^{14} \mathrm{CO}_{2}$, with estimations of average ${ }^{14} \mathrm{CO}_{2}$ concentration of $75 \%$ modern $(\sim 2300 \mathrm{yr} \mathrm{BP})$ in mountain rivers and $97 \%$ modern $(\sim 250 \mathrm{yr} \mathrm{BP})$ in mixed catchments within the Amazon Basin (Mayorga et al., 2005). However, the interpretative focus was on the Amazonian fluvial carbon cycle being fast (Mayorga et al., 2005) and in balance (Gloor et al., 2012). Now, confirmation of old $\mathrm{C}$ in effluxed $\mathrm{CO}_{2}$ indicates that we must consider the slow-turnover carbon cycle processes, such as sedimentary rock and carbonate weathering, in order to understand the controls of long-term carbon balance within the basin.

If the aged carbon originates from carbonate weathering, as indicated for our study site by the correlations with [Ca], then the efflux of this aged component is likely to be more significant in areas closer to the Andean headwaters to which our Tambopata study site also belongs. Therefore the fraction of aged carbon in $\mathrm{CO}_{2}$ efflux from the main stem and major tributaries further downstream is likely to be lower as indicated by ${ }^{14} \mathrm{C}$ analysis of DIC from these systems (Mayorga et al., 2005). However, even if the efflux of weathering-derived 
aged $\mathrm{CO}_{2}$ would be limited to the headwater regions, it still forms an important pathway of returning stored fossil carbon to the atmosphere and hence should not be disregarded. Rather, its significance within the Amazon Basin needs to be assessed in order to correctly describe models of carbon flux pathways on which land use or environmental change are often imposed.

Furthermore, if aged carbon is being delivered in groundwater to the streams then the fractional contribution from these carbon sources will be higher in the dry season and the evaded gas will be older. Such a response in the New Colpita Stream was evident as water levels dropped. However, further investigation of the age of evasion over different seasons is needed to verify this seasonality in flux source. This investigation requires end-member characterization including dating of DOC, POC (separating the fine and coarse fractions that have different origins; Hedges et al., 1986a, 2000; Bird et al., 1992; Townsend-Small et al., 2005) and soil carbon to verify the origin and age of older fractions.

Globally, information on $\mathrm{CO}_{2}$ evasion age is still scarce. Ages exist from temperate (Billett et al., 2007; Garnett et al., 2012, 2013; Leith et al., 2014) and boreal (Billett et al., 2012) streams draining peatland and forest (Tittel et al., 2013), some with agricultural land (McCallister and del Giorgio, 2012), North American rivers (Raymond et al., 2004; Zeng and Masiello, 2010) and streams (Han Lu et al., 2014). The studies vary in their methodologies from direct measurement of evasion $\mathrm{CO}_{2}$ to measurement of dissolved $\mathrm{CO}_{2}$ and DIC. The dates range from modern to $\sim 2800 \mathrm{yr} \mathrm{BP}$, but there is high spatial and temporal variability in the evasion age, which needs to be understood in detail to better understand the terrestrial-aquatic-atmospheric continuum.

Furthermore, data are lacking from many regions. There are large areas of carbonate lithology in Asia (Copard et al., 2007) with major rivers such as Changjiang, Xijiang, Mekong, Brahmaputra and Ganges characterized by carbonate weathering contributions higher than those found in the Amazon River (Gaillardet et al., 1999). Also some large European rivers (Seine, Rhone, Rhine and Po) have higher carbonate weathering inputs (Gaillardet et al., 1999), and, here, outgassing of aged carbon can be prevalent. Additionally, large deposits of organic-rich shales are found in the Himalayas (Copard et al., 2007). Old C may also come from the ecosystem more directly. For example, disturbed peat swamps in SE Asia are exporting old DOM (Moore et al., 2013), which, if respired, may result in aged $\mathrm{CO}_{2}$ evasion.

Clearly, to obtain a global understanding of the importance of slow carbon cycling in various ecosystems, the age of $\mathrm{C}$ fuelling $\mathrm{CO}_{2}$ efflux has to be considered. We need a more secure understanding: turnover times have recently been identified as the key model inputs in terrestrial ecosystems (Keenan et al., 2013); knowing the speed of carbon cycling of different aquatic pools is as crucial as links between terrestrial, marine and atmospheric $\mathrm{C}$ reservoirs, and the sensitivities of each to environmental drivers of change are likely to differ.
The DyDOC model uses ${ }^{14} \mathrm{C}$ data to simulate the soil carbon cycle and DOC production, and considers pool turnover times (Tipping et al., 2007) but larger ecosystem-scale models lack age as a constraint on pool residence time or the rate of C transfer (Schmidt et al., 2011; Huntingford et al., 2013; Bony et al., 2013). Future projections of the importance of the Amazon as a global C sink focus largely on an ecosystem response to land use, e.g. burning and clearing, or to acute meteorological events, e.g. drought, and of this we cannot be certain without knowing the significance of older carbon contributions. The carbon cycling models need to be revised to incorporate the rates of carbon flow and residence times, rather than just transfer between reservoirs. Without this we are neither identifying the significance of differing $\mathrm{C}$ contributions to atmospheric $\mathrm{CO}_{2}$ efflux, nor do we have the secure foundations to impose a driver of change.

Acknowledgements. This study was funded by UK NERC Amazonica grant NE/F005482/1. We thank Eric Cosio and Eliana Esparza Ballón for help with logistics and research permits, Rosa Maldonado Maldonado, Susanne Wörner and Fabian Limonchi Tamamoto for assistance with fieldwork, Kenneth Roberts for the help with GIS analysis, Alison McDonald for assistance with DIC analysis, Valeria Donets and Karen-Jane Miller for the calcium analyses. We are grateful to Bryan Mark of Ohio State University, USA, for collecting the LiDAR data, and to Chris Hopkinson of the University of Lethbridge, Canada, Ross Hill of Bournemouth University, UK, and Doreen Boyd of the University of Nottingham, UK, for processing and supplying the LiDAR data in the format of digital terrain and canopy models, which allowed the detection of small streams. We thank NASA LP DAAC for ASTER GDEM data that allowed analysis of river catchment areas.

Edited by: S. Bouillon

\section{References}

Abril, G., Martinez, J. M., Moreira-Turcq, P., Benedetti, M. F., Vidal, L., Meziane, T., Kim, J.-H., Bernardes, M. C., Savoye, N., Deborde, J., Lima Souza, E., Albéric, P., Fernandes, M., de Souza, L., and Roland, F.: Amazon River carbon dioxide outgassing fuelled by wetlands, Nature, 505, 395-398, 2014.

Alin, S. R., Rasera, M. d. F. F. L., Salimon, C. I., Richey, J. E., Holtgrieve, G. W., Krusche, A. V., and Snidvongs, A.: Physical controls on carbon dioxide transfer velocity and flux in low-gradient river systems and implications for regional carbon budgets, J. Geophys. Res.-Biogeo., 116, G01009, doi:10.1029/2010jg001398, 2011.

Berner, R. A.: The long-term carbon cycle, fossil fuels and atmospheric composition, Nature, 426, 323-326, 2003.

Bianchi, T. S.: The role of terrestrially derived organic carbon in the coastal ocean: A changing paradigm and the priming effect, $\mathrm{P}$. Natl. Acad. Sci. USA, 108, 19473-19481, 2011.

Billett, M. F., Garnett, M. H., and Hardie, S. M. L.: A direct method to measure ${ }^{14} \mathrm{CO}_{2}$ lost by evasion from surface waters, Radiocarbon, 48, 61-68, 2006. 
Billett, M. F., Garnett, M. H., and Harvey, F.: UK peatland streams release old carbon dioxide to the atmosphere and young dissolved organic carbon to rivers, Geophys. Res. Lett., 34, L23401, doi:10.1029/2007gl031797, 2007.

Billett, M. F., Garnett, M. H., Dinsmore, K. J., Dyson, K. E., Harvey, F., Thomson, A. M., Piirainen, S., and Kortelainen, P.: Age and source of different forms of carbon released from boreal peatland streams during spring snowmelt in E. Finland, Biogeochemistry, 111, 273-286, 2012.

Bird, M. I., Fyfe, W. S., Pinheiro-Dick, D., and Chivas, A. R.: Carbon isotope indicators of catchment vegetation in the Brazilian Amazon, Global Biogeochem. Cy., 6, 293-306, 1992.

Bony, S., Bellon, G., Klocke, D., Sherwood, S., Fermepin, S., and Denvil, S.: Robust direct effect of carbon dioxide on tropical circulation and regional precipitation, Nat. Geosci., 6, 447-451, 2013.

Bouchez, J., Beyssac, O., Galy, V., Gaillardet, J., France-Lanord, C., Maurice, L., and Moreira-Turcq, P.: Oxidation of petrogenic organic carbon in the Amazon floodplain as a source of atmospheric $\mathrm{CO}_{2}$, Geology, 38, 255-258, 2010.

Boyd, D. S., Hill, R. A., Hopkinson, C., and Baker, T. R.: Landscape-scale forest disturbance regimes in southern Peruvian Amazonia, Ecol. Appl., 23, 1588-1602, 2013.

Bullen, T. D. and Kendall, C.: Tracing of weathering reactions and water flowpaths: a multi-isotope approach, in: Isotope Tracers in Catchment Hydrology, edited by: Kendall, C. and McDonnell, J. J., Elsevier, Amsterdam, 611-646, 1998.

Clark, K. E., Hilton, R. G., West, A. J., Malhi, Y., Gröcke, D. R., Bryant, C. L., Ascough, P. L., Robles Caceres, A., and New, M.: New views on "old" carbon in the Amazon River: Insight from the source of organic carbon eroded from the Peruvian Andes, Geochem. Geophy. Geosy., 14, 1644-1659, 2013.

Copard, Y., Amiotte-Suchet, P., and Di-Giovanni, C.: Storage and release of fossil organic carbon related to weathering of sedimentary rocks, Earth Planet. Sci. Lett., 258, 345-357, 2007.

Dittmar, T., de Rezende, C. E., Manecki, M., Niggemann, J., Coelho Ovalle, A. R., Stubbins, A., and Bernardes, M. C.: Continuous flux of dissolved black carbon from a vanished tropical forest biome, Nat. Geosci., 5, 618-622, 2012.

Doctor, D. H., Kendall, C., Sebestyen, S. D., Shanley, J. B., Ote, N., and Boyer, E. W.: Carbon isotope fractionation of dissolved inorganic carbon (DIC) due to outgassing of carbon dioxide from a headwater stream, Hydrol. Process., 22, 2410-2423, 2008.

Faure, G.: Principles of Isotope Geology, 2nd Edn., John Wiley and Sons, New York, 1986.

Fyllas, N. M., Patino, S., Baker, T. R., Nardoto, G. B., Martinelli, L. A., Quesada, C. A., Paiva, R., Schwarz, M., Horna, V., Mercado, L. M., Santos, A., Arroyo, L., Jimenez, E. M., Luizao, F. J., Neill, D. A., Silva, N., Prieto, A., Rudas, A., Silviera, M., Vieira, I. C. G., Lopez-Gonzalez, G., Malhi, Y., Phillips, O. L., and Lloyd, J.: Basin-wide variations in foliar properties of Amazonian forest: phylogeny, soils and climate, Biogeosciences, 6, 2677-2708, doi:10.5194/bg-6-2677-2009, 2009.

Gaillardet, J., Dupre, B., Louvat, P., and Allegre, C. J.: Global silicate weathering and $\mathrm{CO}_{2}$ consumption rates deduced from the chemistry of large rivers, Chem. Geol., 159, 3-30, 10.1016/s0009-2541(99)00031-5, 1999.
Garnett, M. H., Dinsmore, K. J., and Billett, M. F.: Annual variability in the radiocarbon age and source of dissolved $\mathrm{CO}_{2}$ in a peatland stream, Sci. Total Environ., 427, 277-285, 2012.

Garnett, M. H., Hardie, S. M. L., Murray, C., and Billett, M. F.: Radiocarbon dating of methane and carbon dioxide evaded from a temperate peatland stream, Biogeochemistry, 114, 213-223, 2013.

Gloor, E., Brienen, R., Galbraith, D., Feldpausch, T. R., J., S., Guyot, J.-L., J.C., E., Lloyd, J., and Phillips, O. L.: Intensification of the Amazon hydrological cycle over the last two decades, Geophys. Res. Lett., 40, 1-5, 2013.

Gloor, M., Gatti, L., Brienen, R., Feldpausch, T. R., Phillips, O. L., Miller, J., Ometto, J. P., Rocha, H., Baker, T., de Jong, B., Houghton, R. A., Malhi, Y., Aragão, L. E. O. C., Guyot, J. L., Zhao, K., Jackson, R., Peylin, P., Sitch, S., Poulter, B., Lomas, M., Zaehle, S., Huntingford, C., Levy, P., and Lloyd, J.: The carbon balance of South America: a review of the status, decadal trends and main determinants, Biogeosciences, 9, 5407-5430, doi:10.5194/bg-9-5407-2012, 2012.

Hardie, S. M. L., Garnett, M. H., Fallick, A. E., Rowland, A. P., and Ostle, N. J.: Carbon dioxide capture using a zeolite molecular sieve sampling system for isotopic studies (C-13 and C-14) of respiration, Radiocarbon, 47, 441-451, 2005.

Hedges, J. I., Clark, W. A., Quay, P. D., Richey, J. E., Devol, A. H., and Santos, U. D.: Compositions and fluxes of particulate organic material in the Amazon river, Limnol. Oceanogr., 31, 717-738, 1986a.

Hedges, J. I., Ertel, J. R., Quay, P. D., Grootes, P. M., Richey, J. E., Devol, A. H., Farwell, G. W., Schmidt, F. W., and Salati, E.: Organic C-14 in the Amazon river system, Science, 231, 11291131, 1986 b.

Hedges, J. I., Mayorga, E., Tsamakis, E., McClain, M. E., Aufdenkampe, A., Quay, P., Richey, J. E., Benner, R., Opsahl, S., Black, B., Pimentel, T., Quintanilla, J., and Maurice, L.: Organic matter in Bolivian tributaries of the Amazon River: A comparison to the lower mainstream, Limnol. Oceanogr., 45, 1449-1466, 2000.

Hill, R. A., Boyd, D. S., and Hopkinson, C.: Relationship between canopy height and Landsat ETM plus response in lowland Amazonian rainforest, Remote Sens. Lett., 2, 203-212, 2011.

Hilton, R. G., Galy, A., and Hovius, N.: Riverine particulate organic carbon from an active mountain belt: Importance of landslides, Global Biogeochem. Cy., 22, GB1017, 10.1029/2006gb002905, 2008.

Hoefs, J.: Stable Isotope Geochemistry, Springer, Variations of Stable Isotope Ratios in Nature, 93-229, 2004.

Householder, J. E., Janovec, J. P., Tobler, M. W., Page, S., and Lähteenoja, O.: Peatlands of the 4 Madre de Dios River of Peru: Distribution, Geomorphology, and Habitat Diversity, Wetlands, 32, 359-368, 2012.

Huntingford, C., Zelazowski, P., Galbraith, D., Mercado, L. M., Sitch, S., Fisher, R., Lomas, M., Walker, A. P., Jones, C. D., Booth, B. B. B., Malhi, Y., Hemming, D., Kay, G., Good, P., Lewis, S. L., Phillips, O. L., Atkin, O. K., Lloyd, J., Gloor, E., Zaragoza-Castells, J., Meir, P., Betts, R., Harris, P. P., Nobre, C., Marengo, J., and Cox, P. M.: Simulated resilience of tropical rainforests to $\mathrm{CO}_{2}$-induced climate change, Nat. Geosci., 6 , 268-273, 2013. 
Keenan, T. F., Davidson, E. A., Munger, J. W., and Richardson, A. D.: Rate my data: quantifying the value of ecological data for the development of models of the terrestrial carbon cycle, Ecol. Appl., 23, 273-286, 2013.

Keller, C. K. and Bacon, D. H.: Soil respiration and georespiration distinguished by transport analyses of vadose $\mathrm{CO}_{2},{ }^{13} \mathrm{CO}_{2}$, and ${ }^{14} \mathrm{CO}_{2}$, Global Biogeochem. Cy., 12, 361-372, 1998.

Leith, F. I., Garnett, M. H., Dinsmore, K. J., Billett, M. F., and Heal, K. V.: Source and age of dissolved and gaseous carbon in a peatland-riparian-stream continuum: a dual isotope $\left({ }^{14} \mathrm{C}\right.$ and $\left.\delta^{13} \mathrm{C}\right)$ analysis, Biogeochemistry, $119,415-433$, doi:10.1007/s10533-014-9977-y, 2014.

Leithold, E. L., Blair, N. E., and Perkey, D. W.: Geomorphologic controls on the age of particulate organic carbon from small mountainous and upland rivers, Global Biogeochem. Cy., 20, GB3022, 10.1029/2005gb002677, 2006.

Levin, I., Hammer, S., Kromer, B., and Meinhardt, F.: Radiocarbon observations in atmospheric $\mathrm{CO}_{2}$ : Determining fossil fuel $\mathrm{CO}_{2}$ over Europe using Jungfraujoch observations as background, Sci. Total Environ., 391, 211-216, 2008.

Lu, Y. H., Bauer, J. E., Canuel, E. A., Chambers, R. M., Yamashita, Y., Jaffé, R., and Barrett, A.: Effects of land use on sources and ages of inorganic and organic carbon in temperate headwater streams, Biogeochemistry, 119, 275-292, doi:10.1007/s10533014-9965-2, 2014.

Malhi, Y., Farfán Amézquita, F., Doughty, C. E., Silva-Espejo, J. E., Girardin, C. A. J., Metcalfe, D. B., Aragão, L. E. O. C., HuaracaQuispe, L. P., Alzamora-Taype, I., Eguiluz-Mora, L., Marthews, T. R., Halladay, K., Quesada, C. A., Robertson, A. L., Fisher, J. B., Zaragoza-Castells, J., Rojas-Villagra, C. M., Pelaez-Tapia, Y., Salinas, N., Meir, P., and Phillips, O. L.: The productivity, metabolism and carbon cycle of two lowland tropical forest plots in south-western Amazonia, Peru, Plant Ecol. Diversity, 7, 85105, doi:10.1080/17550874.2013.820805, 2014.

Mayorga, E., Aufdenkampe, A. K., Masiello, C. A., Krusche, A. V., Hedges, J. I., Quay, P. D., Richey, J. E., and Brown, T. A.: Young organic matter as a source of carbon dioxide outgassing from Amazonian rivers, Nature, 436, 538-541, 2005.

McCallister, S. L. and del Giorgio, P. A.: Evidence for the respiration of ancient terrestrial organic $\mathrm{C}$ in northern temperate lakes and streams, P. Natl. Acad. Sci. USA, 109, 16963-16968, 2012.

McMichael, C. H., Correa-Metrio, A., and Bush, M. B.: PreColumbian fire regimes in lowland tropical rainforests of southeastern Peru, Palaeogeogr. Palaeocl., 342, 73-83, 2012.

Meybeck, M.: Global chemical weathering of surficial rocks estimated from river dissolved loads, Am. J. Sci., 287, 401-428, 1987.

Moore, S., Evans, C. D., Page, S. E., Garnett, M. H., Jones, T. G., Freeman, C., Hooijer, A., Wiltshire, A. J., Limin, S. H., and Gauci, V.: Deep instability of deforested tropical peatlands revealed by fluvial organic carbon fluxes, Nature, 493, 660-663, 2013.

Moquet, J.-S., Crave, A., Viers, J., Seyler, P., Armijos, E., Bourrel, L., Chavarri, E., Lagane, C., Laraque, A., Lavado Casimiro, W. S., Pombosa, R., Noriega, L., Vera, A., and Guyot, J.-L.: Chemical weathering and atmospheric/soil $\mathrm{CO}_{2}$ uptake in the Andean and Foreland Amazon basins, Chem. Geol., 287, 1-26, 2011.
Neu, V., Neill, C., and Krusche, A. V.: Gaseous and fluvial carbon export from an Amazon forest watershed, Biogeochemistry, 105, 133-147, 2011.

Parnell, A. C., Inger, R., Bearhop, S., and Jackson, A. L.: Source Partitioning Using Stable Isotopes: Coping with Too Much Variation, Plos One, 5, e9672, doi:10.1371/journal.pone.0009672, 2010.

Petsch, S. T., Berner, R. A., and Eglinton, T. I.: A field study of the chemical weathering of ancient sedimentary organic matter, Org. Geochem., 31, 475-487, 2000.

Polsenaere, P. and Abril, G.: Modelling $\mathrm{CO}_{2}$ degassing from small acidic rivers using water $\mathrm{pCO}_{2}$, DIC and delta ${ }^{13} \mathrm{C}$-DIC data, Geochim. Cosmochim. Ac., 91, 220-239, 2012.

Quesada, C. A., Lloyd, J., Schwarz, M., Patino, S., Baker, T. R., Czimczik, C., Fyllas, N. M., Martinelli, L., Nardoto, G. B., Schmerler, J., Santos, A. J. B., Hodnett, M. G., Herrera, R., Luizao, F. J., Arneth, A., Lloyd, G., Dezzeo, N., Hilke, I., Kuhlmann, I., Raessler, M., Brand, W. A., Geilmann, H., Moraes Filho, J. O., Carvalho, F. P., Araujo Filho, R. N., Chaves, J. E., Cruz Junior, O. F., Pimentel, T. P., and Paiva, R.: Variations in chemical and physical properties of Amazon forest soils in relation to their genesis, Biogeosciences, 7, 1515-1541, doi:10.5194/bg-7-15152010, 2010.

Quesada, C. A., Lloyd, J., Anderson, L. O., Fyllas, N. M., Schwarz, M., and Czimczik, C. I.: Soils of Amazonia with particular reference to the RAINFOR sites, Biogeosciences, 8, 1415-1440, doi:10.5194/bg-8-1415-2011, 2011.

Rasera, M. d. F. F. L., Ballester, M. V. R., Krusche, A. V., Salimon, C., Montebelo, L. A., Alin, S. R., Victoria, R. L., and Richey, J. E.: Estimating the surface area of small rivers in the southwestern Amazon and their role in $\mathrm{CO}_{2}$ outgassing, Earth Interact., 12, 1 16, doi:10.1175/2008ei257.1, 2008.

Raymond, P. A. and Bauer, J. E.: Riverine export of aged terrestrial organic matter to the North Atlantic Ocean, Nature, 409, 497500, 2001.

Raymond, P. A., Bauer, J. E., Caraco, N. F., Cole, J. J., Longworth, B., and Petsch, S. T.: Controls on the variability of organic matter and dissolved inorganic carbon ages in northeast US rivers, Mar. Chem., 92, 353-366, 2004.

Richey, J. E., Melack, J. M., Aufdenkampe, A. K., Ballester, V. M., and Hess, L. L.: Outgassing from Amazonian rivers and wetlands as a large tropical source of atmospheric $\mathrm{CO}_{2}$, Nature, 416, 617620, 2002.

Rigsby, C. A., Hemric, E. M., and Baker, P. A.: Late Quaternary Paleohydrology of the Madre de Dios River, southwestern Amazon Basin, Peru, Geomorphology, 113, 158-172, 2009.

Salimon, C., Sousa, E. d. S., Alin, S. R., Krusche, A. V., and Ballester, M. V.: Seasonal variation in dissolved carbon concentrations and fluxes in the upper Purus River, southwestern Amazon, Biogeochemistry, 114, 245-254, 2013.

Schillawski, S. and Petsch, S.: Release of biodegradable dissolved organic matter from ancient sedimentary rocks, Global Biogeochem. Cy., 22, GB3002, doi:10.1029/2007gb002980, 2008.

Schmidt, M. W. I., Torn, M. S., Abiven, S., Dittmar, T., Guggenberger, G., Janssens, I. A., Kleber, M., Koegel-Knabner, I., Lehmann, J., Manning, D. A. C., Nannipieri, P., Rasse, D. P., Weiner, S., and Trumbore, S. E.: Persistence of soil organic matter as an ecosystem property, Nature, 478, 49-56, 2011. 
Sioli, H.: The Amazon Limnology and landscape ecology of a mighty tropical river and its basin, Dr. W Junk Publishers, Kluwer Academic Publishers Group, 1984.

Tipping, E., Smith, E. J., Bryant, C. L., and Adamson, J. K.: The organic carbon dynamics of a moorland catchment in NW England, Biogeochemistry, 84, 171-189, 2007.

Townsend-Small, A., McClain, M. E., and Brandes, J. A.: Contributions of carbon and nitrogen from the Andes Mountains to the Amazon River: Evidence from an elevational gradient of soils, plants, and river material, Limnol. Oceanogr., 50, 672-685, 2005.

Townsend-Small, A., McClain, M. E., Hall, B., Noguera, J. L., Llerena, C. A., and Brandes, J. A.: Suspended sediments and organic matter in mountain headwaters of the Amazon River: Results from a 1-year time series study in the central Peruvian Andes, Geochim. Cosmochim. Ac., 72, 732-740, 2008.
Waldron, S., Scott, E.M., and Soulsby, C.: Stable isotope analysis reveals lower-order river dissolved inorganic carbon pools are highly dynamic. Environ. Sci. Technol., 41, 6156-6162, 2007.

Ward, N. D., Keil, R. G., Medeiros, P. M., Brito, D. C., Cunha, A. C., Dittmar, T., Yager, P. L., Krusche, A. V., and Richey, J. E.: Degradation of terrestrially derived macromolecules in the Amazon River, Nat. Geosci., 6, 530-533, 2013.

Zeng, F.-W. and Masiello, C. A.: Sources of $\mathrm{CO}_{2}$ evasion from two subtropical rivers in North America, Biogeochemistry, 100, 211 225, 2010.

Zimmermann, M., Meir, P., Bird, M. I., Malhi, Y., and Ccahuana, A. J. Q.: Climate dependence of heterotrophic soil respiration from a soil-translocation experiment along a $3000 \mathrm{~m}$ tropical forest altitudinal gradient, Eur. J. Soil Sci., 60, 895-906, 2009. 